\title{
Perubahan Kadar Vitamin dan Mineral pada Fermentasi Tempe Gude (Cajanus cajan L.)
}

\author{
Yuni Sine ${ }^{\mathrm{a}}$ dan Endang S. Soetarto \\ a Biologi, Universitas Timor, Kefamenanu, TTU - NTT, Indonesia, email : Yuni_sine@yahoo.com
}

${ }^{b}$ Fakultas Biologi, Universitas Gadjah Mada, Yogyakarta. Indonesia

\section{Article Info}

\section{Article history:}

Received 8 Mei 2018

Received in revised form 19 Juni 2018

\section{DOI:}

https://doi.org/10.32938/slk.v1i1.414

\section{Keywords:}

Tempe

Fermentasi

Vitamin

Mineral
Accepted 4 Juli 2018

\begin{abstract}
Abstrak
Tempe merupakan makanan tradisional Indonesia yang kaya akan vitamin dan mineral mudah dicerna oleh tubuh. Bahan yang lazimnya digunakan sebagai substrat fermentasi tempe adalah kacang kedelai (Glicyne max), akan tetapi tidak semua daerah di Indonesia dapat ditumbuhi oleh kacang kedelai, oleh karena itu dibutuhkan substrat alternatif untuk fermentasi tempe. Kacang gude (Cajanus cajan L.) dapat dijadikan sebagai substrat alternatif fermentasi tempe, hal ini dikarenakan kacang gude mempunyai kandungan gizi yang cukup baik dan memiliki kandungan vitamin dan mineral yang dibutuhkan oleh tubuh. Selain itu, kacang gude dapat tumbuh baik di daerah kering seperti NTT. Namun demikian sebagian mineral tersebut terikat dengan senyawa asam fitat yang merupakan tripsin inhibitor, sehingga proses pengolahan seperti fermentasi merupakan salah satu cara untuk menguraikan senyawa asam fitat. Pada penelitian ini telah dilakukan pengujian berupa penentuan kadar abu, nitrogen, vitamin dan mineral dengan metode standar, dilakukan sebelum dan setelah fermentasi. Kadar abu mengalami penurunan setelah fermentasi, kadar nitrogen, kadar besi, kadar kalsium dan kadar fosfor juga mengalami penurunan,
\end{abstract} sedangkan kandungan vitamin $\mathrm{B}_{12}$ meningkat $16,56 \%$; jika dibandingkan dengan biji gude.

\section{Pendahuluan}

Vitamin dan mineral merupakan faktor yang sangat penting dalam makanan, Karena dibutuhkan oleh tubuh. Tubuh tidak dapat memproduksi semua vitamin dan mineral, oleh Karena itu tubuh membutuhkan asupan nutrisi berupa vitamin dan mineral dari luar tubuh (Mukhtadi $d k k ., 1993$ ). Sumber vitamin dan minera bagi tubuh manusia berasal dari makanan dan minuman yang dikonsumsi. Di alam banyak terdapat sumber makanan yang nutrisinya baik bagi tubuh. Namun tidak semua nutrisi tersebut dapat langsung dicerna oleh tubuh. Untuk itu pengolahan sumber daya makanan sangat dibutuhkan, banyak cara untuk mengolah makanan di antaranya dengan melakukan fermentasi. Proses fermentasi membuat bahan makanan lebih mudah dicerna oleh tubuh, karen terjadinya proses penguraian oleh mikrobia yang berperan dalam fermentasi (MKM \& M.Kes, t.t.)

Proses fermentasi dapat dilakukan pada bahan makanan berupa kacangkacang, yang menghasilkan produk fermentasi berupa tempe. Tempe umumny menggunakan kacang kedelai sebagai substrat (Ayu Dwinaningsih, 2010), akan tetapi kacang kedelai tidak dapat tumbuh di semua daerah di Indonesia, untuk itu dibutuhkan substrat alternatif, kacang gude merupakan salah satu alternatif karena memiliki kandungan nutrisi yang baik, serta dapat tumbuh baik di daerah kering seperti NTT. Penelitian ini dilakukan untuk mengetahui perubahan kada vitamin dan mineral pada kacang gude dan tempe gude. Pada biji kacang gude mengandung senyawa asam fitat (Priyanto, 2016), asam fitat ini mengika mineral yang ada di dalam kacang gude, untuk itu proses fermentasi akan membantu menghidrolisis asam fitat pada proses perendaman selain itu mikrobia yang aktif dalam fermentasi yaitu jamur Rhizopus mampu menghasilkan enzim fitase yang akan menguraikan asam fitat menjadi fosfor dan inositol (Tarumingkeng $d k k ., 2004$ ).

Dua kelompok vitamin terdapat pada tempe, yaitu larut air (vitamin B kompleks) dan larut lemak (vitamin A, D, E, dan K). Tempe merupakan sumber vitamin $\mathrm{B}$ yang sangat potensial. Jenis vitamin yang terkandung dalam tempe antara lain vitamin B1, B2, asam pantotenat, asam nikotinat, vitamin B6, dan $\mathrm{B}_{12}$. Vitamin $\mathrm{B}_{12}$ umumnya terdapat pada produk-produk hewani dan tidak dijumpai pada makanan nabati (sayuran, buah-buahan, dan biji-bijian), namun tempe mengandung vitamin $B_{12}$ sehingga tempe menjadi satu-satunya sumber vitamin yang potensial dari bahan pangan nabati. Kenaikan kadar vitamin $\mathrm{B}_{12}$ paling mencolok pada pembuatan tempe. Kadar vitamin $\mathrm{B}_{12}$ dalam tempe berkisa antara 1,5 sampai $6,3 \mu \mathrm{g}$ per $100 \mathrm{~g}$ tempe kering. Jumlah ini telah dapat mencukupi kebutuhan vitamin $\mathrm{B}_{12}$ seseorang per hari. Dengan adanya vitamin $\mathrm{B}_{12}$ pada tempe, para vegetarian tidak perlu merasa khawatir akan kekurangan vitamin $\mathrm{B}_{12}$, sepanjang mereka melibatkan tempe dalam menu hariannya (Mulyowidarso dkk., 1991) Vitamin $\mathrm{B}_{12}$ pada tempe dihasilkan oleh bakteri yang ikut serta dalam proses fermentasi, seperti pada saat perendaman, dan pengupasan kulit, sehingga terjadi peningkatan vitamin $B_{12}$

Tempe mengandung mineral makro dan mikro dalam jumlah yang cukup. Jumlah mineral besi, tembaga, dan seng. Kapang tempe dapat menghasilkan enzim fitase yang akan menguraikan asam fitat (yang mengikat beberapa mineral) menjadi fosfor dan inositol. Dengan terurainya asam fitat, mineralmineral tertentu (seperti besi, kalsium, magnesium, dan zink) menjadi lebih tersedia untuk dimanfaatkan tubuh (Tamang dkk., 2016). Kadar abu merupakan campuran dari komponen anorganik atau mineral yang terdapat pada suatu bahan pangan. Bahan pangan terdiri dari $96 \%$ bahan anorganik dan air, sedangkan sisanya merupakan unsur-unsur mineral. Unsur juga dikenal sebagai zat organik atau kadar abu. Kadar abu tersebut dapat menunjukkan total mineral dalam suatu bahan pangan. Bahan-bahan organik dalam proses pembakaran akan terbakar tetapi komponen anorganiknya tidak, karena itulah disebut sebagai kadar abu (Sudarmadji, 1989).

\section{Metode}

a. Penentuan Kadar Abu dengan Cara Kering
Kurs porselen dengan tutupnya dipijarkan dalam muffle furnace. Dinginkan dalam oven, kemudian masukkan ke dalam desikator sampai dingin. Baru kemudian ditimbang. Sampel ditimbang dalam kurs porselen yang telah diketahui beratnya $(2 \mathrm{~g})$, selanjutnya panaskan di atas kompor listrik sehingga bahan menjadi arang kemudian dipijarkan dalam muffle suhu $600^{\circ} \mathrm{C}$ selama \pm 6 jam sampai menjadi abu berwarna keputih-putihan, biarkan muffle sampai menunjukkan suhu kamar, kemudian baru dibuka tutupnya. Kemudian kurs dimasukkan ke dalam eksikator sampai dingin, baru kemudian ditimbang (Apriyantono $d k k ., 1996$ ).

b. Penentuan Kadar Nitrogen dengan Metode Mikro Kjeldahl

Sampel keping gude yang telah dihaluskan dan tempe gude yang telah dihaluskan ditimbang sebanyak $60 \mathrm{mg}$. Dimasukkan ke dalam labu Kjeldahl kapasitas $50 \mathrm{ml}$ dan tambahkan $2 \mathrm{ml}$ asam sulfat (93-98\% bebas N). Tambahkan $20 \mathrm{ml} \mathrm{H}_{2} \mathrm{SO}_{4}$ pekat. Sampel didestruksi pada suhu $410^{\circ} \mathrm{C}$ selama kurang lebih 1 jam sampai larutan jernih lalu didinginkan. Setelah dingin, ke dalam labu

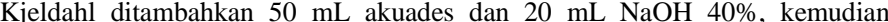
dilakukan proses destilasi dengan suhu destilator $100^{\circ} \mathrm{C}$. Hasil destilasi ditampung dalam labu Erlenmeyer $125 \mathrm{~mL}$ yang berisi campuran $10 \mathrm{~mL}$ asam borat $\left(\mathrm{H}_{3} \mathrm{BO}_{3}\right) 2 \%$ dan 2 tetes indikator bromcherosol green-methyl red yang berwarna merah muda. Setelah volume destilat mencapai $40 \mathrm{~mL}$ dan berwarna hijau kebiruan, maka proses destilasi dihentikan. Lalu destilat dititrasi dengan $\mathrm{HCl} 0,1 \mathrm{~N}$ sampai terjadi perubahan warna merah muda. Volume titran dibaca dan dicatat. Larutan blanko dianalisis seperti sampel (Sudarmadji, 1989).

c. Uji Vitamin $B_{12}$ (Kobalamin)

Prinsip yang digunakan dalam analisis vitamin B12 adalah ekstraksi vitamin kobalamin dengan asam asetat. Sampel dan standar pembanding yang mengandung vitamin kobalamin disuntik ke kolom HPLC pada panjang gelombang yang telah ditentukan. Ekstraksi vitamin B12diawali dengan penimbangan sampel biji gude dan tempe gude sebanyak $5 \mathrm{~g}$ yang mengandung sekitar 40 mikrogram vitamin $\mathrm{B}_{12}$ dimasukkan ke dalam tabung reaksi tertutup. Bufer asetat sebanyak $20 \mathrm{ml}$ dan $0,2 \mathrm{ml}$ larutan kalium-sianida ditambahkan pada tabung reaksi. Tabung dimasukkan ke dalam penangas air mendidih selama 30 menit, lalu didinginkan dan diencerkan sampai $50 \mathrm{ml}$ dengan air suling dan disaring dengan kertas whatman 42. Homogenisasi selama 5 menit dengan ultrasonic dan didiamkan pada suhu ruang sampai dingin. Penambahan $25 \mathrm{ml}$ metanol dan ditepatkan sampai volume $50 \mathrm{ml}$ dengan asam asetat $2 \%$. Sampel disentrifuse pada $4000 \mathrm{rpm}$ selama 30 menit. Supernatan dipisahkan untuk disuntikkan ke HPLC (Hofstetter \& Roche, 1991).

d. Penetapan Mineral dengan Menggunakan Metode Spektrofotometer

Metode ini untuk menentukan kadar fosfor, besi dan kalsium pada tempe gude dan biji gude. Sesudah penghilangan bahan-bahan organik dengan pengabuan kering atau basah residu dilarutkan dalam asam encer. Larutan disebarkan dalam nyala api yang ada di dalam alat AAS sehingga absorsi atau emisi logam dapat dianalisa dan diukur pada panjang gelombang tertentu.

Pereaksi yang digunakan: HCL $6 \mathrm{~N}, 3 \mathrm{~N}$ dan $0,3 \mathrm{~N}$, Lantanum chloride $10 \% \mathrm{w} / \mathrm{v}$, aquades bebas ion, kertas saring Whatman No. 541. Kertas saring dicuci menggunakan dengan HCL $3 \mathrm{~N}$ untuk menghilangkan "tracemetal"). Larutan stok standar $1000 \mathrm{mg} / \mathrm{L}$ yang dibuat dari sejumlah pereaksi "AR Grade" dalam $25 \mathrm{ml}$ HCL 3N kemudian diencerkan menjadi $250 \mathrm{ml}$ dengan akuades. Larutan standar dibuat dari pengenceran larutan stock standar dengan air (jika persiapan sampel dengan pengabuan basah) atau HCL $0,3 \mathrm{~N}$ (pengabuan kering) sampai konsentrasinya berada dalam kisaran kerja logam yang bersangkutan.

Cara kerja:

- Larutan abu berasal dari pengabuan basah

Larutan abu dipindahkan ke dalam labu takar, ditepatkan sampai tanda tera dengan air, dicampur merata.

- Abu berasal dari pengabuan kering
Absorpsi Atom / Atomic Absorpsion Spectrophotomethy (AAS) 
HCL 6N ditambahkan sebanyak $6 \mathrm{~mL}$ ke dalam cawan atau pinggan berisi abu, kemudian dipanaskan pada pemanas (seperti hot plate dengan pemanasan rendah sampai kering). Ditambahkan $15 \mathrm{~mL}$ HCL $3 \mathrm{~N}$ ke dalam cawan, kemudian cawan dipanaskan di atas pemanas sampai mulai mendidih. Didinginkan dan disaring dengan kertas saring, filtrate dimasukkan ke dalam labu takar yang sesuai. Ditambahkan $10 \mathrm{~mL}$ HCL $3 \mathrm{~N}$ ke dalam cawan, kemudian dipanaskan sampai larutan mendidih. Kemudian didinginkan, disaring dan masukkan filtrat ke dalam labu takar. Cawan dicuci dalam air sedikitnya tiga kali, air cucian disaring lalu dimasukkan ke dalam labu takar. Untuk penentuan kadar kalsium ditambahkan $5 \mathrm{~mL}$ larutan lantanum klorida untuk setiap $100 \mathrm{~mL}$ larutan. Didinginkan dan isi labu diencerkan sampai tanda tera dengan air. Blanko disiapkan dengan menggunakan sejumlah pereaksi yang sama dan tahapan yang sama. Selanjutnya dilakukan kalibrasi alat dan penetapan sampel.

\section{Hasil dan Pembahasan}

Vitamin dan mineral pada biji gude dan tempe gude, terdiri dari kadar abu, kadar nitrogen, kadar karbon, kadar vitamin $\mathrm{B}_{12}$, kadar besi, kadar kalsium, dan kadar fosfor

Tabel 1. Kandungan vitamin dan mineral biji gude dan tempe gude

\begin{tabular}{llll}
\multicolumn{1}{c}{ Parameter uji } & Biji gude & Tempe gude & Persyaratan (SNI) \\
\hline Kadar abu $(\%)$ & 3,585 & 0,627 & Maks. 1,5 \\
Kadar nitrogen $(\%)$ & 20,11 & 18,90 & Min. 16 \\
Kadar Vitamin $\mathrm{B}_{12}(\mathrm{mg} / \mathrm{g})$ & 6,08 & 7,087 & - \\
Kadar Besi/Fe $(\mathrm{mg} / \mathrm{L})$ & 29,47 & 14,08 & Min. 4 \\
Kadar Kalsium $(\mathrm{mg} / \mathrm{L})$ & 428,33 & 202,47 & Min. 155 \\
Kadar Fosfor $(\mathrm{mg} / 100 \mathrm{~g})$ & 430,70 & 136,04 & Min .124 \\
\hline
\end{tabular}

Abu merupakan zat anorganik sisa hasil pembakaran suatu bahan makanan. Kandungan abu dan komposisinya tergantung pada macam bahan dan cara pengabuannya. Kadar abu memiliki hubungan dengan mineral suatu bahan Mineral yang terdapat dalam bahan dapat merupakan dua macam garam yaitu garam organik dan garam anorganik. Sebagian bahan makanan, yaitu sekitar $96 \%$ terdiri dari bahan organik dan air. Sisanya terdiri dari unsur-unsur mineral atau kadar abu (Sudarmadji, 1989).

Pada penelitian ini kadar abu pada tempe gude mengalami penurunan jika dibandingkan dengan kadar abu pada biji gude, hal ini dapat disebabkan karena terjadinya hidrolisis pada saat perendaman, Sudarmadji (1996) menyatakan hal ini karena mineral yang terkandung dalam biji gude terlarut dalam air pada saat perendaman, selain itu perebusan juga mempengaruhi penurunan kadar mineral. Rerata kadar abu pada tempe gude adalah $0.627 \%$ Sedangkan pada biji gude sebesar 3,585\%. Kadar abu maksimal pada tempe menurut standar nasional Indonesia yaitu maks $1,5 \%$. Kadar abu pada kacang yang telah difermentasi mengalami penurunan sekitar $82,31 \%$. Besarnya kadar abu berhubungan dengan mineral dalam suatu bahan (Sudarmadji, 1989), jika kadar abu dalam bahan menurun makan kadar mineral bahan akan ikut menurun. Sehingga nilai kadar abu yang tinggi pada biji gude menunjukkan kandungan mineral yang terdapat pada biji gude lebih tinggi dibandingkan dengan kandungan mineral yang terdapat pada tempe gude.

Berdasarkan hasil penelitian kadar nitrogen pada biji gude lebih tinggi dibandingkan dengan kadar nitrogen pada tempe gude, Selama fermentas kandungan protein kasar hanya sedikit yang berubah, tetapi kelarutannya meningkat menjadi kira-kira 5\% (Sudarmadji, 1989). Suhu meningkat selama fermentasi dan akan menurun jika pertumbuhan jamur terhenti, $\mathrm{pH}$ meningkat mungkin disebabkan oleh penurunan kadar nitrogen (Steinkraus dkk., 1965). Steinkraus dkk (1965) melaporkan bahwa penurunan kadar nitrogen dapat terjadi karena perendaman, pembuangan kulit, serta pemasakan.

Penurunan Kadar nitrogen akibat pembuangan kulit, perendaman dan pemasakan 3,9-8,0\% dan selama fermentasi 0,8-1,7\% (Van der maesen, 1989). Kadar N total dari biji gude adalah $20,11 \%$ sedangkan rerata kadar $\mathrm{N}$ total pada tempe gude adalah $18,90 \%$ sehingga kadar nitrogen pada tempe mengalami penurunan sebesar $6,01 \%$.

Pada Tabel 1. menunjukkan sebagian kadar gizi tempe gude lebih rendah dari pada biji gude secara kuantitatif, menurut Murata dkk (1967), bahwa secara kuantitatif, nilai gizi tempe sedikit lebih rendah. Namun, secara kualitatif nilai gizi tempe lebih tinggi karena tempe mempunyai nilai cerna yang lebih baik. Hal ini disebabkan kadar protein yang larut dalam air akan meningkat akibat aktivitas enzim Proteolitik (Murata dkk., 1967).

Vitamin $\mathrm{B}_{12}$ adalah suatu vitamin yang sangat kompleks molekulnya, yang mengandung sebuah atom cobalt (Co) yang terikat mirip dengan besi terikat dalam hemoglobin atau magnesium dalam klorofil (Hermana \& Karyadi, 1996). Vitamin $\mathrm{B}_{12}$ merupakan anggota kelompok kobalamin. Selama fermentasi tempe mengalami pembentukan vitamin $\mathrm{B}_{12}$ sehingga kenaikan jumlah abu berasal dari cobalt (Co pada vitamin $\mathrm{B}_{12}$ ) yang terkandung dalam vitamin $\mathrm{B}$ kompleks tersebut. Vitamin $\mathrm{B}_{12}$ meningkat sebesar $16,56 \%$, vitamin $\mathrm{B}_{12}$ sangat penting karena berguna untuk membantu pembentukan sel darah merah.

Tempe gude mengandung mineral makro dan mikro dalam jumlah yang cukup. Jumlah mineral besi, kalsium, dan fosfor berturut-turut adalah 14,083 $\mathrm{mg} / \mathrm{L} ; 202,478 \mathrm{mg} / \mathrm{L}$; dan 136,04 mg/L setiap $100 \mathrm{~g}$ tempe. Kapang tempe dapat menghasilkan enzim fitase yang akan menguraikan asam fitat (yang mengikat beberapa mineral) menjadi fosfor dan inositol. Dengan terurainya asam fitat, mineral-mineral tertentu (seperti besi, kalsium, magnesium, dan zink) menjadi lebih tersedia untuk dimanfaatkan tubuh. Selain itu, proses perendaman mempengaruhi peningkatan enzim fitase, yang mampu mengurangi zat anti gizi pada biji gude, selama perendaman biji mentah akan terjadi peningkatan enzim fitase sehingga pemecahan fitat akan berlangsung. Selain itu, juga akan terjadi pelarutan fitat ke dalam air rendamannya. Sedangkan perendaman biji rebus dalam air akan menyebabkan penurunan fitat yang relatif besar (Sudarmadji, 1989), asam fitat bersifat larut air sehingga perendaman juga dapat mereduksi kadar fitat.

Kombinasi perendaman dengan pemanasan dan atau blansir (keduanya dilakukan sebelum perendaman) akan mereduksi asam fitat dengan lebih efektif. Pemanasan tidak merusak asam fitat (karena sifat asam fitat dan senyawa fitat merupakan senyawa fosfat yang disintesis secara alami di dalam biji tanaman, banyak terdapat di dalam biji kacang-kacangan dan biji serelia (Torres dkk. 2006), penurunan kadar asam fitat ini berhubungan dengan penurunan fosfor pada tempe gude, karena senyawa fitat merupakan senyawa fosfat yang disintesis oleh tanaman. Berdasarkan penelitian yang dilakukan Torres dkk. (2006), fermentasi dapat mengurangi asam fitat $(48 \%)$, dan aktivitas inhibitor tripsin (39\%). Trenggono (1992) melaporkan bahwa dengan fermentasi, aktivitas enzim tripsin meningkat $45-72 \%$. Namun, fermentasi ini tidak mempunyai pengaruh nyata pada kandungan tannin, karena bahwa tanin merupakan metabolit sekunder yang diekskresikan untuk sistem proteksi, sistem proteksi dengan mekanisme pengikatan protein menjadikan protein akan sukar terdegradasi (Trenggono, 1992).

Selama fermentasi, kapang menghidrolisis senyawa kompleks biji gude menjadi senyawa sederhana dan mengakibatkan derajat ketidakjenuhan asam lemak tempe meningkat, protein dalam bentuk terlarut, produksi vitamin $\mathrm{B}$ meningkat, dan ketersediaan mineral tertentu meliputi besi, kalsium, magnesium dan zink meningkat secara kualitatif serta menghasilkan rasa dan aroma khas tempe (Nout \& Kiers, t.t.; Shurtleff \& Aoyagi, 2001). Hal ini menunjukkan bahwa tempe mempunyai kualitas gizi yang baik karena memiliki senyawa protein, vitamin dan mineral yang dibutuhkan oleh tubuh.

\section{Simpulan}

Kadar abu mengalami penurunan $82,31 \%$ setelah fermentasi, kadar nitrogen mengalami penurunan $6,01 \%$, kadar besi menurun $52.22 \%$, kadar kalsium menurun $52,72 \%$ dan kadar fosfor juga mengalami penurunan sebesar 68,41\%, sedangkan vitamin $\mathrm{B}_{12}$ mengalami peningkatan $16,56 \%$ jika dibandingkan dengan biji gude. Mineral pada saat kacang gude (Cajanus cajan L.) belum difermentasi lebih tinggi secara kuantitatif dibandingkan dengan tempe gude, akan tetapi secara kualitatif tempe gude memiliki daya cerna yang lebih tinggi bagi tubuh, hal ini karena senyawa antigizi pada kacang gude dapat terhidrolisis pada saat proses pembuatan tempe. Mikroorganisme yang aktif dalam proses fermentasi juga mampu menghasilkan enzim fitase yang akan menguraikan asam fitat menjadi fosfor dan inositol.

\section{Pustaka}

Apriyantono, A.., Fardiaz, N.L.P., Sedarnawati \& Budiyanto, S. 1996. Analisis Pangan. Bogor: PAU Pangan dan Gizi IPB.

Ayu Dwinaningsih, E. 2010. Karakteristik kimia dan sensori tempe dengan variasi bahan baku kedelai/beras dan penambahan angkak serta variasi lama fermentasi. PhD Thesis. Solo: UNS.

Hermana, M.K. \& Karyadi, D. 1996. Health significance of tempe for human nutrition. Funny Publishing Limited Partnership, 2(Proceedings of the Second International Soybean Processing and Utilization Conference): $391-$ 394.

Hofstetter, J. \& Roche, V. 1991. Analytical Methods for Vitamin in Food/Pharma Premixes. New York: Basel : F. Hoffmann-La Roche Ltd. New York : Open University Press, Inc.

MKM, D.D.S. \& M.Kes, R.R., DCN t.t. Fakta Ajaib Khasiat Tempe. Jakarta: Penebar Swadaya Grup.

Mukhtadi, D., Palupi, N.S. \& Astawan, M. 1993. Metabolisme zat gizi: sumber fungsi dan kebutuhan bagi tubuh manusia. Jakarta: Pustaka Sinar Harapan.

Mulyowidarso, R.., Fleet, G.. \& Buckle, K.. 1991. Changes in the concentration of organic acids during the soaking of soybeans for tempe production. International Journal of Food Science and Technology, 26: 607-614.

Murata, K., Ikehata, H. \& Miyamoto, T. 1967. Studies on the Nutritional value of tempeh. J. Food Sci., 32: 580.

Nout, M.J.R. \& Kiers, J.L. t.t. Tempe fermentation, innovation and functionality: update into the third millenium. Journal of Applied Microbiology, 98(4): 789-805.

Priyanto 2016. Kandungan Asam Fitat Dan Hen Pada Berbagai Macam Pengolahan Kacang Gude (Cajanus cajan L.).

Shurtleff, W. \& Aoyagi, A. 2001. The book of miso: savory, high-protein seasoning. Volume 1. Ten Speed Press.

Steinkraus, K.H., Buren, V., P, J., Hackler, L.R. \& Hand, D.B. 1965. A pilotplant process for the production of dehydrated tempeh. Food Technol.

Sudarmadji, S. 1989. Analisa bahan makanan dan pertanian. Liberty Yogyakarta bekerja sama dengan Pusat Antar Universitas Pangan dan Gizi Universitas Gadjah Mada.

Tamang, J.P., Shin, D.-H., Jung, S.-J. \& Chae, S.-W. 2016. Functional Properties of Microorganisms in Fermented Foods. Frontiers in Microbiology, 7.

Tarumingkeng, I.R.C., Coto, I.Z. \& Hardjanto, I. 2004. Enzim Fitase Dan Peranannya Dalam Memecah Ikatan Asam Fitat Pada Bahan Pakan. 
Torres, A., Frias, J., Granito, M. \& Vidal-Valverde, C. 2006. Fermented pigeon pea (Cajanus cajan) ingredients in pasta products. Journal of Agricultural and Food Chemistry, 54(18): 6685-6691.

Trenggono 1992. Fisiologi Lepas Pasca Panen. Yogyakarta: Fakultas Teknologi Pertanian UGM.

Van der maesen, L.J.. 1989. Cajanus cajan (L.) Millsp. : Pulses." Pudoc, Wageningen, The Netherlands., 1("Plant Resources of South-East Asia). 